\title{
Investors' response on the deviation between quarterly and annual earnings
}

\author{
Saidatunur Fauzi Saidin 1,*, Mazrah Malek ${ }^{2}$, Daing Nasir Ibrahim ${ }^{3}$ and Phua Lian Kee \\ ${ }^{1}$ Universiti Putra Malaysia, Department of Accounting and Finance, Faculty of Economics and \\ Management, 43400 Serdang, Selangor, Malaysia \\ ${ }^{2}$ Universiti Utara Malaysia, Tunku Intan Shafinaz School of Accountancy, Faculty of Business, 06010 \\ Sintok, Kedah, Malaysia \\ ${ }^{3}$ Universiti Malaysia Pahang, Canseleri Tun Abdul Razak, 26600 Pekan, Pahang, Malaysia \\ ${ }^{4}$ Universiti Sains Malaysia, School of Management, 11800 USM, Penang, Malaysia
}

\begin{abstract}
Despite the benefits of timely information, concerns have been raised on the reliability of the quarterly accounts. The occurrence of deviation between audited annual accounts and cumulative quarterly accounts indicates the misstatements in the latter. This study examines investors' response towards the occurrence of the deviation. Data is based on 792 listed companies of Bursa Malaysia in 2012. The results of the OLS regression show that the companies without earnings deviation have significantly higher earnings response coefficient than companies experiencing earnings deviation. It is also found that understated quarterly earnings companies have higher earnings response coefficient than overstated companies. Results imply that investors place higher reliability on the quarterly accounts produced by companies without earnings deviation. Higher reliability is placed on the understated quarterly earnings companies as compared to overstated companies. Findings suggest that investors do value the occurrence and types of earnings deviation. Therefore, steps should be taken to overcome the occurrence of deviation.
\end{abstract}

\section{Introduction}

The quarterly accounts which cover an entity's activities for a three-month period rather than twelve-months as reported by the annual accounts allow for a more frequent and timely dissemination on the progress of an entity. Frequent information helps to reduce uncertainties [1]. Timely information increases the relevance of the information [2]. It can be observed that many countries have mandatorily required their listed companies to produce quarterly reports. In Malaysia, the listed companies on the Bursa Malaysia are mandatorily required in March 1999 to produce quarterly accounts for quarters ending on or after $31^{\text {st }}$ July 1999 as a response to the Asian Financial Crisis in 1997/98 and in replace of the half-yearly reporting which was made mandatory since 1987 [1,3]. Currently, the requirement is regulated under Chapter 9.22 of the Listing Requirements of Bursa Malaysia, where listed companies are mandated to produce their quarterly accounts not later than two months after end of each quarter. Part A of Appendix 9B of the Listing

* Corresponding author: saidatunur@upm.edu.my 
Requirements further elaborates the information that needs to be disclosed in the accounts. However, like in many other countries, the accounts are not required to be audited.

Despite the benefits of frequent and timely information, many have questioned the reliability of quarterly accounts $[2,4,5]$. Earlier studies by [5] and [6] assess the reliability of quarterly accounts based on the occurrence of earnings deviation between audited annual accounts and cumulative quarterly accounts. While audited accounts are considered as high quality, the studies argued that the occurrence of earnings deviation represents the misstatements in quarterly accounts. The concern by the Bursa Malaysia has led to mandatory disclosure announcement, whereby companies with 10-percent or more in deviation are required to make immediate announcements concerning the deviation together with complete explanations. While theoretically the occurrence of earnings deviation is an evidence of low quality quarterly accounts, users' perspective on the deviation is still unclear. As the main users of quarterly accounts, investors' perspective towards the occurrence of earnings deviation is important to be examined. An earlier study in Malaysia by [5] examines the effect of audit committee characteristics on the occurrence of earnings deviation. Meanwhile, the study by [6] only examines the occurrences of earnings deviation among the U.S listed companies. This study extends both studies by focusing on the effect of earnings deviation on investors' reliance to the subsequently produced quarterly earnings.

\section{Literature review}

Financial reporting is a main mechanism in dissemination of asymmetry information between the managers and the stakeholders [7]. Even though, financial information can also be relieved by other means, financial accounts provide the most comprehensive and reliable source of information. Many have shown that the accounts help in the economic decisionmaking process $[8,9]$. Therefore, it is very crucial for the users to have quality financial accounts to avoid misleading judgments. Traditionally, financial accounts are prepared for external users on an annual basis and this has been a common practice across countries. However, annual accounts suffer from timely problem, whereby some of the information reported by the accounts may become irrelevant at the time of production [2]. To overcome this timely problem, interim reporting is required. Countries such as Malaysia, Singapore and the U.S are among those which require their listed companies to produce interim reporting on a quarterly basis, while in the U.K, only half-yearly reporting is required. Interim reporting helps to release frequent information to stakeholders which then reduces uncertainties and enhances confidence over the company's state of affairs [1].

Despite the benefits of frequent and timely information, many are sceptical about the reliability of information provided by the quarterly accounts. As noted by [2]: "while interim reports increase the relevance of the financial statements through more timely communication of position and results, their usefulness to users is also a function of their reliability" (p.268). The concern on the reliability of quarterly accounts arises mainly due to nature that quarterly accounts are not required to be audited by external auditors in most jurisdictions. Unaudited accounts expose them to the risk of errors and manipulations by the managers [3]. Empirical evidence by prior studies has also indicated for the need of auditors' involvement in the quarterly accounts. For example [10] and [11] found that the quarterly earnings which are audited have a higher earnings response coefficient than those without auditor involvement. A study by [12] of financial analysts' perceptions had found that the mean reliability increases with increasing auditor association. Attempts have been made by regulators in some countries such as in the U.S and Thailand by requiring limited audit review of quarterly accounts. Many have highlighted the fourth quarter settling-up phenomenon in the preparation of quarterly accounts where it is argued that the fourth 
quarter accounts are used by companies to reverse out the misstatements in the earlier three quarters $[1,3]$. Conceptually, researchers have argued that since only annual accounts are audited, a company may intentionally misstate their earlier three quarterly accounts and then, make adjustments or corrections in the fourth quarter accounts to avoid the deviation between the quarterly (cumulative) and annual accounts. As claimed by [4], companies generally do not publish the fourth quarter accounts per se, but simply the difference between the annual and the cumulative of the first three quarters' accounts.

Theoretically, the occurrence of earnings deviation between quarterly (cumulatively) and audited annual accounts represents low reliability of quarterly accounts [5,6]. It denotes the occurrence of misstatements in quarterly earnings where higher (lower) earnings reported in quarterly accounts than in audited accounts represents overstatements (understatements). Even though, the occurrence of deviation indicates that necessary adjustments have been made in audited annual accounts to correct the accounts, negative perceptions towards the reliability of quarterly accounts by investors may still exist. They may still use the subsequent quarterly earnings produced by these companies in the equity valuation but the reliance is lower than the quarterly earnings produced by companies without deviation. Therefore, it is postulated that companies without earnings deviation will have higher earnings response coefficient than companies with earnings deviation.

\section{Methodologies}

Data is based on listed companies of Bursa Malaysia in year 2012. As at 31 December 2011, 956 companies are listed but 109 companies are excluded due to inability to determine the occurrence of earnings deviation. Another 5 companies which have changed their financial year, 50 companies which have been delisted during or after year 2012 are also excluded and thus, bringing the sample companies to only 792 companies. The sample consists of 317 (40 percent) without earnings deviation companies, 275 (35 percent) overstated quarterly earnings companies and 201 (25 percent) understated quarterly earnings companies. Data on quarterly earnings, audited annual earnings and asset size are collected through the Bursa Malaysia's website, while data on share prices and composite index are collected from Bursa Station. The earnings response model as proposed by [13] is used in testing the hypothesis. The model is originated from the semi-strong efficient market model by [14]. [13] postulates that by holding the prior uncertainty about cash flows constant, the earnings response coefficient will increase with the perceived quality of the earnings' signal. Thus, in this study, the occurrence of earnings deviation acts as a moderating variable to the relationship between earnings performance and abnormal return. Therefore, the Ordinary Least Square regression is used and takes the following form:

$$
C A R=E P+P R O F I T+S I Z E+E P^{*} D E V I A T E
$$

CAR covers for two days of event window; on announcement date and a day after announcement date $(t 0, t 1)$ measured by [15] market model. EP is measured by dividing the difference between the earnings per share of current quarter and prior quarter with the market value of share two days prior to the earnings' announcement. PROFIT is measured by dichotomous measurement, where the value of 1 , if the observed company has profit and 0 , if the observed company incurred a loss in the quarter. SIZE is measured by natural logarithm of total assets. DEVIATE is measured by the difference between profit attributable to owners of the company reported in cumulative quarterly accounts and audited annual accounts. Dichotomous measurement is used where the value of 1 , if the observed company does not have earnings deviation and 0 , if the observed company has earnings deviation in prior year. 


\section{Results}

Univariate analyses are conducted by separating the sample into two groups; companies with earnings deviation and companies without earnings deviation, to examine the mean and frequency differences between the two groups. As can be observed from Table 1, both types of companies are found to have identical mean for CAR. However, earnings deviation companies have better performance (EP), but have smaller assets than without earnings deviation companies. However, only the difference in SIZE is significant between the two groups.

Table 1. Descriptive and univariate analyses (continuous measurements)

\begin{tabular}{|c|c|c|c|}
\hline Variable & $\begin{array}{c}\text { Deviation Companies } \\
\text { Mean (std. deviation) }\end{array}$ & $\begin{array}{c}\text { Without Deviation Companies } \\
\text { Mean (std. deviation) }\end{array}$ & T-test \\
\hline CAR & $.001(.058)$ & $.001(.048)$ & .047 \\
\hline EP & $.245(35.815)$ & $-.045(13.035)$ & .276 \\
\hline SIZE & $8.451(.628)$ & $8.565(.765)$ & $-4.576^{*}$ \\
\hline \multicolumn{2}{|r}{} \\
\hline
\end{tabular}

Meanwhile, from Table 2, it can be observed that the percentage of without deviation companies with positive CAR, negative EP and has PROFIT are larger than deviation companies. However, only the distribution based on profit is significantly different between the two groups.

Table 2. Descriptive and univariate analyses (dichotomous measurements)

\begin{tabular}{|ll|c|c|c|}
\hline Variable & & $\begin{array}{c}\text { Deviation Companies } \\
\text { Number (Percentage) }\end{array}$ & $\begin{array}{c}\text { Without Deviation Companies } \\
\text { Number (Percentage) }\end{array}$ & Chi-square \\
\hline CAR & 0 & $987(51.947)$ & $631(49.763)$ & 1.452 \\
& 1 & $913(48.053)$ & $637(50.237)$ & .407 \\
\hline EP & 0 & $973(51.210)$ & $664(52.366)$ & $9.178^{*}$ \\
\hline PROFIT & 1 & $927(48.789)$ & $604(47.634)$ & $292(23.028)$ \\
& 1 & $529(27.842)$ & $976(76.972)$ & *significant at 1 percent level \\
\hline \multicolumn{5}{|r|}{$1,371(72.158)$}
\end{tabular}

Based on the univariate analyses, it can be concluded that companies without earnings deviation have bigger size of assets and are more likely to have profit than companies with earnings deviation. On the other hand, both types of companies have identical cumulative abnormal return and earnings performance.

Table 3 presents correlation results and as can be observed, CAR are all positive and significantly correlated with EP, PROFIT, and EP*DEVIATION. The correlation between CAR and SIZE is negative. Meanwhile, the correlations among the independent variables are considerably low. While the threshold of 0.8 is usually used for possible multicollinearity problem, this indicates that multicollinearity issue is not critical [16].

Table 3. Correlation analyses

\begin{tabular}{|c|c|c|c|c|}
\hline Variable & CAR & EP & SIZE & PROFIT \\
\hline EP & $.126^{*}$ & - & - & - \\
\hline SIZE & -.020 & -.004 & - & - \\
\hline PROFIT & $.152^{*}$ & $.109^{*}$ & $.250^{*}$ & - \\
\hline EP*DEVIATION & $.115^{*}$ & $.285^{*}$ & .018 & $.099^{*}$ \\
\hline
\end{tabular}

*significant at 1 percent level 
Meanwhile, Table 4 presents the results of OLS regression. The adjusted R-squared is 0.043 and is significant at one percent. It implies that the independent variables used in the model explain about 4 percent of the variation in the CAR. The low adjusted R-squared is consistent with the earlier studies in Malaysia by [17] of 0.10 and in other countries such as by [18] and [19] of around 0.03. The coefficients of EP and PROFIT are both positive and significant at a one percent level. The positive coefficient of PROFIT implies that profiting companies have positive abnormal returns and losses companies have negative abnormal returns of shares. It is consistent with the earlier findings by [19], [20] and [21]. Meanwhile, the positive coefficient of EP implies that the higher the earnings performance, the higher the abnormal returns, which is consistent with the findings by earlier studies [17, $22,23]$. Both of the results are consistent with the argument by [14] that the positive information received by capital market will result in a positive abnormal return, while negative information will result in a negative abnormal return of shares. Meanwhile, the coefficient SIZE is negative and significant at a one percent level. The negative coefficient implies that the bigger the size of assets, the lower the abnormal return of shares which is consistent with the findings of earlier studies by [20] and [25].

As hypothesized, the coefficient of the variable representing the interaction of earnings performance and earnings deviation, EP*DEVIATION is positive and significant at a one percent level. This implies that companies without deviation have higher earnings response coefficients than companies experiencing deviation. The investors of the capital market place higher reliability on quarterly earnings produced by companies without deviation than companies experiencing deviation. The result is consistent with the findings by earlier studies such as [18], [19] and [24] on earnings response coefficients and argument by [13] that investors' response to the earnings will increase with the perceived quality of earnings performance. The investors may still rely on the quarterly accounts produced by companies experiencing deviation in their equity valuation decision, but the reliance is lower than the quarterly accounts produced by the companies without deviation. While quarterly earnings provide value relevance information to investors, the occurrence of earnings deviation decreases investors' reliability to the earnings' numbers.

Table 4. Ordinary Least Square Regression statistics

\begin{tabular}{|c|c|c|c|}
\hline Variable & Expected sign & $\mathrm{t}$ & Coefficient \\
\hline EP & + & 4.85 & $.0001^{*}$ \\
\hline SIZE & - & -3.24 & $-.0046^{*}$ \\
\hline PROFIT & + & 8.23 & $.0185^{*}$ \\
\hline EP*DEVIATION & + & 4.17 & $.0005^{*}$ \\
\hline Constant & & 2.22 & $.0263^{*}$ \\
\hline Adjusted R-squared & & $.0425^{*}$ \\
\hline \multicolumn{4}{|l}{} \\
*significant at 1 percent level
\end{tabular}

An additional analysis is conducted to examine the difference in response of different types of deviation by using the sample of deviation companies only. In this analysis, DEVIATION is measured by 1 , if the companies experience understated deviation and 0 , if the companies experience overstated deviation. As presented in Table 5, the result is consistent with the earlier regression. The coefficients for EP and PROFIT are significant and positive, while SIZE is significant and negative. Meanwhile, EP*DEVIATION is positive and significant, which implies that companies experiencing understated deviation have higher earnings response coefficient than companies experiencing overstated deviation. Investors place higher reliability on earnings produced by understated companies 
than those from overstated companies. The types of earnings deviation is valued by the investors in placing their reliability to the quarterly earnings.

Table 5. Ordinary Least Square Regression statistics (deviation companies)

\begin{tabular}{|c|c|c|c|}
\hline Variable & Expected sign & $\mathrm{t}$ & Coefficient \\
\hline EP & + & 2.87 & $.0002 *$ \\
\hline SIZE & - & -2.42 & $-.0051 *$ \\
\hline PROFIT & + & 6.44 & $.0194 *$ \\
\hline EP*DEVIATION & + & 2.42 & $.0002 *$ \\
\hline Constant & & 1.71 & $.0002 * *$ \\
\hline Adjusted R-squared & & & $.0369 *$ \\
\hline
\end{tabular}

\section{Conclusions}

The reliability of quarterly accounts has been criticised and prior studies have indicates questionable reliability of the accounts. Earlier studies have argued that the occurrence of earnings deviation between cumulative quarterly accounts and audited annual accounts as an evidence of the misstated quarterly accounts. However, investors' views on the deviation are still unclear. This study argues that the investors may still rely on the quarterly accounts produced by companies experiencing earnings deviation, but the reliance is lower than the quarterly accounts produced by companies without earnings deviation. Using data of listed companies on Bursa Malaysia for year 2012, OLS regression results show that companies without earnings deviation have higher earnings response coefficient than companies experiencing earnings deviation. Furthermore, it is also found that companies experiencing understated quarterly earnings have higher earnings response coefficient than companies experiencing overstated quarterly earnings. The results suggest for the need of companies and regulators to enhance the quality of quarterly accounts. Perhaps by requiring external auditors' involvement in the production of quarterly accounts may resolve the occurrence of earnings deviation.

This paper is funded under the Fundamental Research Grant Scheme (FRGS) by the Malaysia Ministry of Higher Education.

\section{References}

1. K. N. I. K. Ismail, S. N. Abdullah, Asian J. of Fin. and Acctg., 1 (2009)

2. K. Lightstone, N. M. Young, T. McFadden, Acctg. Pers., 11 (2012)

3. K. N. I. K. Ismail, R. Chandler, IIUM J. of Econ. and Mgmt., 13 (2005)

4. W. A. Collins, W. S. Hopwood, J. C. McKeown, J. of Acctg. Res., 22 (1984)

5. D. N. Ibrahim, K. J. Raman, S. F. Saidin, Sing. Mgmt. Rev., 31 (2009)

6. M. Al-Darayseh, J. F. Brown Jr., J. of App. Bus. Res., 8 (1992)

7. G. Whittington, Acctg. Bus. Res., 23 (1993)

8. B. Lev, J. A. Ohlson, J. of Acctg. Res., 20 (1982)

9. M. Penno, J. of Acctg. Res., 23 (1985)

10. D. Manry, S. L. Tiras, C. M. Wheatley, Acctg. Rev., 78 (2003)

11. M. Malek, S. F. Saidin, M. N. H. Osman, DLSU Bus. and Econ. Rev., 25 (2016)

12. K. Pany, C. H. Smith, J. of Acctg. Res., 20 (1982)

13. R. Holthausen, R. Verrecchia, J. of Acctg. Res., 26 (1988)

14. E. F. Fama, J. of Fin., 25 (1970)

15. W. F. Sharpe, J. of Fin., 19 (1964) 
16. D.N. Gujarati, McGraw Hill, 2003.

17. K. Ismail, R. A. Rahman, J. of Bus. Mgmt., 6 (2012)

18. J. Krishnan, H. Sami, Y. Zhang, Auditing: A J. of Prac. and Theo., 24 (2005)

19. J. R. Francis, B. Ke, Rev. of Acctg. Stud., 11 (2006)

20. F. A. Gul, J. Tsui, D. S. Dhaliwal, Acctg. and Fin., 46 (2006)

21. K. E. Hackenbrack, C. E. Hogan, Cont. Acctg. Res., 19 (2002)

22. J. Lee, C. W. Park, J. of Bus. Fin. and Acctg., 27 (2000)

23. W. R. Landsman, E. L. Maydew, J. of Acctg. Res., 40 (2002)

24. I. Haw, D. Qi ,W. Wu, J. of Acctg. and Fin., 23 (2008)

25. S. W. Teoh, T. J. Wong, Acctg. Rev., 68 (1993) 